九州大学学術情報リポジトリ

Kyushu University Institutional Repository

\title{
Descriptions of new species of galatheids from the Western Pacific (Crustacea, Dacapoda)
}

Miyake, Sadayoshi

Zoological Laboratory, Department of Agriculture, Kyushu University

Baba, Ke i ji

Zoological Laboratory, Department of Agriculture, Kyushu University

https://doi.org/10.5109/22756

出版情報: 九州大学大学院農学研究院紀要. 14 (2)，pp.203-212，1967-03. Kyushu University バージョン：

権利関係 : 
Journal of the Faculty of Agriculture, Kyushu University, Vol. 14, No. 2

March 30, 1967

\author{
Descriptions of new species of galatheids from \\ the Western Pacific (Crustacea, Dacapoda)*
}

Sadayoshi Mryake and Keiji BabA

Up till now galatheid specimens as well as the other decapod crustaceans have been collected in the Zoological Laboratory, Kyushu University, chiefly from the Japanese waters, Bonin Islands, Ryukyu Islands and Palau Islands, some of which have been reported in the previous papers (Miyake, 1953; Miyake and Baba, 1963, 1964, 1965, 1966a, 1966b). The species described here each is represented by a single or a few individuals, however, it is thought advisable to publish here in order to make them known without delay.

We wish to express our gratitude to Emeritus Professor Hiroshi Ohshima of Kyushu University, M. J. A. and to the late Dr. Hayato Ikeda for the opportunity to study the materials collected in their expeditions. Our thanks are also due to Professor Itsuo Kubo of Tokyo University of Fisheries and Professor Kojiro Kato of Saitama University for providing us with the materials.

\title{
Family Chirostylidae Ortmann
}

\section{Uroptychus triangularis sp. nov. (Fig. 1)}

Rostrum about half as long as carapace with pointed tip; dorsal surface smooth and slightly concave. Carapace including rostrum as long as broad, triangular in shape. Lateral margin of carapace with six spines of stocky shape, the third one being the largest; dorsal surface armed with about five minute spines on gastric region. Outer orbital angle slightly spinulated.

Thoracic sternum shorter than broad, deeply concave at anterior portion; anterior margin smoothly embayed.

Basal segment of antennular peduncle armed with a prominent spine on outer distal margin. Second segment of antennal peduncle with a minute spine at outer marginal angle; a large spine also placed at

* Contributions from the Zoological Laboratory, Faculty of Agriculture, Kyushu University, No. 353 . 
each of the inner marginal angles of third and fourth segments; antennal scale slightly longer than fourth segment.

Merus of third maxilliped longer than ischium, broadest at median, bearing four spines on distal half of inner margin. Carpus armed with two small spines on outer margin, its outer distal marginal angle extending to form a large spine.

Chelipeds equal in length and shape, about two and a half times as long as carapace including rostrum. Arm rather short; inner margin with four large spines on distal half and two spinules behind them; four spines also placed on ventral surface close to inner marginal spines; outer margin spinulated at distal angle with two tubercles on proximal margin; dorsal surface with two rows of spines being three in number on each one. Wrist almost equal to arm in length, armed with six spines of equal size on inner margin, its inner distal corner

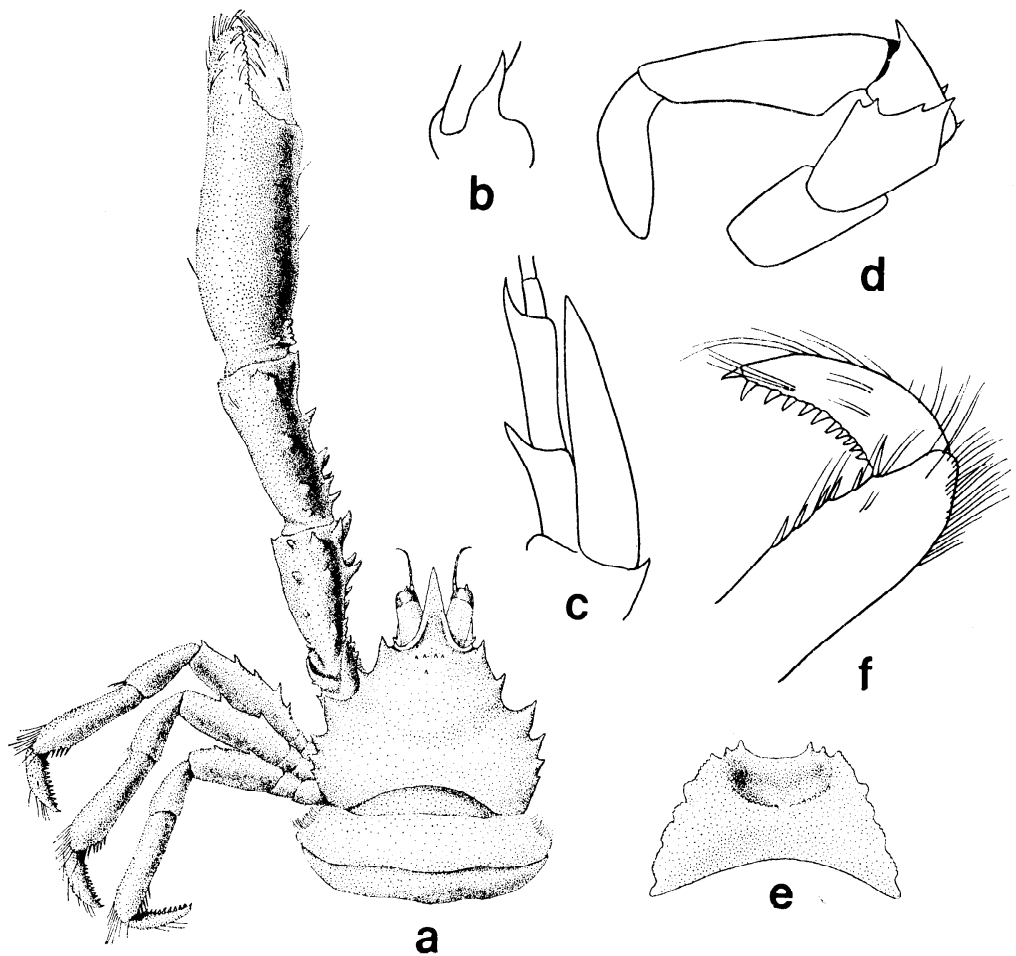

Fig. 1. Uroptychus triangularis sp. nov.

a, Animal in dorsal view, $\times 5$; b, basal segment of left antennule, $\times 28$; c, left antennal peduncle, first segment omitted, $\times 28$; d, endopod of left third maxilliped, setae omitted, $\times 18 ;$ e, sternal segments, $\times 12 ;$ f, distal segments of left first ambulatory leg, $\times 18$. 
slightly spinulated; dorsal surface armed with about five spinules on median line; outer margin smooth. Palm rather stout, less than one and a half times as long as wrist, and slightly shorter than two and a half times the length of movable finger; surface smooth but proximal portion of inner margin armed with four tubercles, and also with a single tubercle near the inner marginal tubercles on dorsal surface. Fingers less than two and a half times as long as palm, not gapped, and thickly furnished with short setae; cutting margin minutely dentate.

Merus of first ambulatory leg armed with five spines on outer (upper) margin, its inner (lower) margin smooth. Carpus smooth, not armed with spines. Propodus with four slender spines near inner distal margin and thickly furnished with coarse setae distally. Dactylus sparsely furnished with setae on surface; about eleven spines placed on inner margin, decreasing their size proximally. Following two pairs of ambulatory legs similar to first pair in shape but reduced in number of spines on merus.

Measurements in holotype (in $\mathrm{mm}$ ):

\begin{tabular}{|c|c|}
\hline ength of carapace including rostrum & 4.3 \\
\hline Breadth of carapace ............... & 4.0 \\
\hline Length of rostrum................ & 1.5 \\
\hline Length of cheliped................... & 14.3 \\
\hline 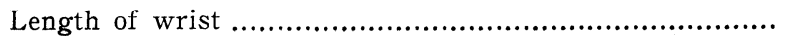 & 3.6 \\
\hline 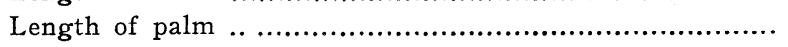 & 4.5 \\
\hline 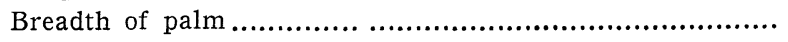 & 1.7 \\
\hline 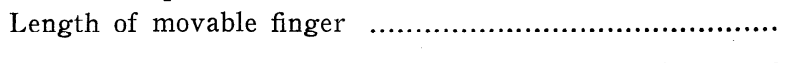 & 2.0 \\
\hline
\end{tabular}

Remarks. This species differs from other members of the genus in having a triangular-shaped carapace with large lateral spines.

Type. Holotypc, ovigcrous female, ZLKU No. 4883 ; near Mukojima, Bonin Islands; July 18-19, 1938 ; H. Ikeda leg.

\section{Family Calatheidae Dana \\ Galathea kuboi sp. nov. (Fig. 2)}

Rostrum about one and a half times as long as broad, armed with four teeth on each side; dorsal surface flat and thickly furnished with short setae. Carapace not including rostrum about as long as broad; cervical groove distinct; lateral margin armed with seven spines, two of them placed on hepatic region and the other five on branchial region; dorsal surface without any complete transverse ridges, but very setose; the setae short; a strigose stria placed just behind cervical groove. Anterior portion of gastric region armed with about eight spinules or tubercles arranged transversely. Outer orbital angle rounded and unarmed. 
Basal segment of antennular peduncle with three spines on distal margin, the outermost being the largest. Anterior prolongation of first segment of antenna not acutely spined, but blunt and long; second segment with both inner and outer distal marginal spines of large size; third segment without any spines.

Ischium of third maxilliped about as long as broad, with a small spine at inner distal angle; inner toothed ridge armed with about 26 closely placed denticles. Merus with two inner marginal spines of large size and also with two outer marginal spines of small size on distal portion. Carpus smooth on outer margin.

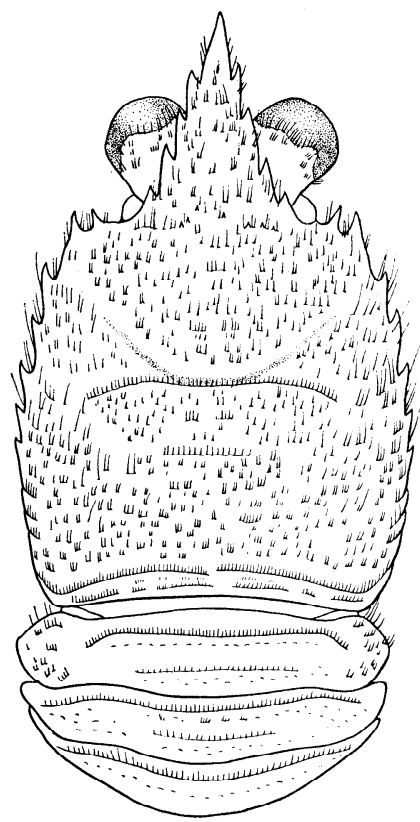

a

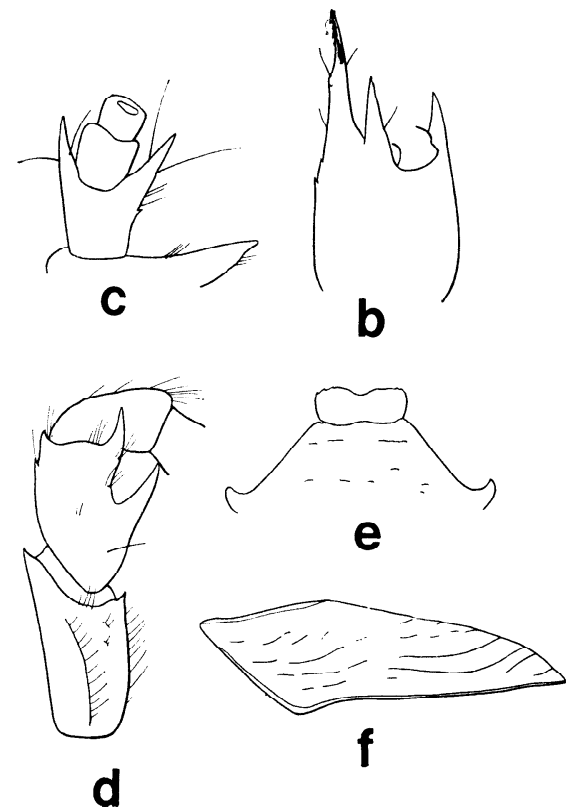

d

Fig. 2. Galathea kuboi sp. nov.

a, Animal in dorsal view, legs wanting, $\times 8$; b, basal segment of right antennule, $\times 17$; c, right antennal peduncle, $\times 17$; , endopod of right third maxilliped, $\times 16$; e, anterior part of sternal segments, $\times 11$; $\mathrm{f}$, left pterygostomial flap, $\times 8$.

Pterygostomial flap without any complete striae on surface but with broken ones. Chelipeds and ambulatory legs wanting.

Epipods not present on cheliped and ambulatory legs.

Measurements in holotype (in $\mathrm{mm}$ ): 


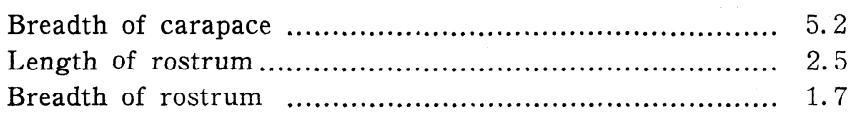

Remarks. The species is allied to Galathea biunguiculata Miyake in having no complete transverse ridge on the carapace, but it is distinguished from the latter by the shape of the sternum of the third thoracic segment.

Type. Holotype, male, ZLKU No. 13248 ; off Daiozaki, Middle Japan; Aug. 26, 1936 ; I. Kubo leg.

\section{Galathea ohshimai sp. nov. (Fig. 3)}

Rostrum one and a half times as long as broad; lateral margin armed with four acute teeth; dorsal surface flat and smooth. Carapace not including rostrum as long as broad; cervical groove not distinct; two spines on first transverse ridge of gastric region; lateral margin with six acute spines on right side and five on the left, the anterior third wanting. Outer orbital angle pyramid-shaped.

Basal segment of antennule with three well developed spines on distal margin, the outermost larger than the others. First segment of antennal peduncle sharply spined at lower distal end, extending beyond the third segment of peduncle; second segment with both of the inner and outer distal marginal spines; third segment without any spines.

Ischium of third maxilliped shorter than merus with a spine on inner distal angle; inner toothed ridge with about 18 closely placed denticles. Merus armed with a wcll developed median spine and a small distal spine on inner margin, and with a distal spine of small size and two slight eminences on outer margin. Carpus unarmed but with three protuberances.

Chelipeds equal in length and shape, about twice as long as carapace, sparsely furnished with long setae. Arm stout with two large and two other small inner marginal spines, two rows of dorsal spines, and one large and a small outer marginal spine. Wrist longer than finger with three spines on inner margin, the second onc being the largest; a rather large spine situated below the third of inner marginal spines; dorsal surface with two longitudinal rows of spinules which are five in number on each one; outer margin with two or three spines. Palm with three inner marginal spines on proximal half and three other marginal spines on distal half; dorsal surface also with a longitudinal row of five spinules; a series of spines (about 13 in number) also placed along the outer margin extending to outer margin of immovable finger. Fingers slightly gapped, about one and a half times as long as palm; each of the fingers with an eminence and small tubercles on cutting margin; three spinules placed on outer margin of 
movable finger.

$\Lambda$ mbulatory legs not scale-like above but sparsely furnished with long setae. Merus of first ambulatory leg armed with nine outer (upper) marginal spines, and its inner (lower) margin spined at distal angle. Carpus with four outer marginal and two dorsal spincs; inner margin not spined. Propodus with three spines on proximal portion of outer margin and with five slender and movable spines keeping equal

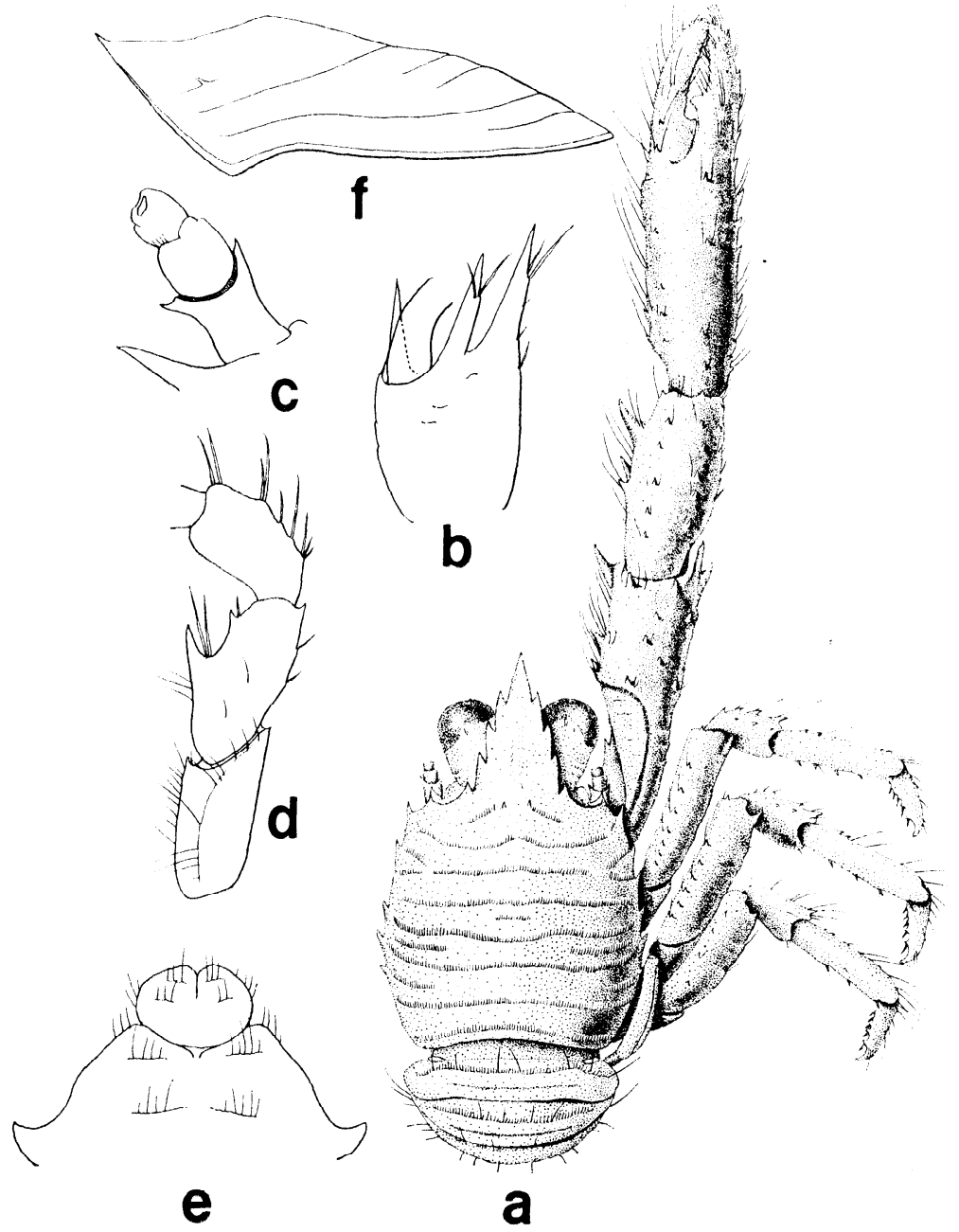

Fig. 3. Galathea ohshimai sp. nov.

a, Animal in dorsal view, $\times 9$; b, basal segment of left antennule, $\times 26$;

c, left antennal peduncle, $\times 26$; d, endopod of left third maxilliped, $\times 26$;

e, anterior part of sternal segments, $\times 26 ; \mathrm{f}$, left pterygostomial flap, $\times 18$. 
distances on inner margin. Dactylus serrated on inner margin with five broad setae, each springing from base of serrated tooth. Following two pairs of ambulatory legs similar to the first in shape.

Pterygostomial flap with a spine on anterior portion of surface.

Cheliped with epipods.

Measurements in holotype (in $\mathrm{mm}$ ):

\begin{tabular}{|c|c|}
\hline Length of carapace including rostrum. & 4.6 \\
\hline 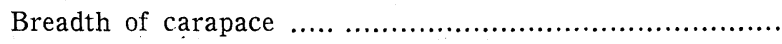 & 3.0 \\
\hline Length of rostrum & 1.6 \\
\hline Breadth of rostrum. & 1.0 \\
\hline Length of cheliped.. & 11.2 \\
\hline Length of wrist .... & 2. \\
\hline Length of palm. & \\
\hline Breadth of palm ... & \\
\hline Length of movable finger...... & \\
\hline
\end{tabular}

Remarks. The species is closely related to Galathea orientalis Stimpson from which it differs in having an outer orbital angle of pyramidal shape and in having no spines on the outer margin of the carpus of the third maxilliped.

Type. Holotype, male, ZLKU No. 4595; Ngarsmau, Babldáob I., Palau Is. $\left(7^{\circ} 37^{\prime} \mathrm{N}, 134^{\circ} 33^{\prime} \mathrm{E}\right), 10 \mathrm{~m}$ deep ; July 14,1939 ; H. Ohshima and S. Miyake leg.

\section{Munida tenuipes sp. nov. (Fig. 4)}

Rostrum spiniform, horizontal and about two and a half times as long as supraorbital spine. Carapace not including rostrum nearly as long as broad; dorsal surface devoid of setae. Cervical groove rather distinct. Epigastric region with two spines; margin of hepatic region with a well developed anterolateral spine and a spinule; anterior branchial region with two spines laterally; a spine placed on posterior branchial region laterally. One pair of postcervical spines present. Second to fourth abdominal segments armed with transverse rows of spines on their dorsal surface, the number of spines presented by six, four and two respectively.

Basal segment of antennule armed with two terminal spines, the inner one being the longer, and two outer lateral spines, of which the anterior is the longer and slightly exceeds the outer terminal spine. First segment of antennal peduncle with a prolonged spine at lower distal margin; second segment armed with a small outer distal marginal spine and a long inner distal marginal spine.

Ischium of third maxilliped thin and slightly longer than merus, armed with a large spine on each of the inner and outer distal margin. 
Merus thickly furnished with plumose setae; the inner margin with a well developed spine at the middle, and the outer margin spined on distal end.

Chelipeds about three times as long as carapace including rostrum, depressed, scaliform and devoid of long setae. Arm with ten spines on inner margin; dorsal surface armed with about ten spinules situated close to the outer margin excluding a spine at distal corner, and also with four spinules situated close to proximal one-third of inner margin; proximal half of ventral surface with six spines; a spine also placed at distal margin of ventral surface. Wrist about as long as finger; inner margin with four spines including one at distal end; distal margin

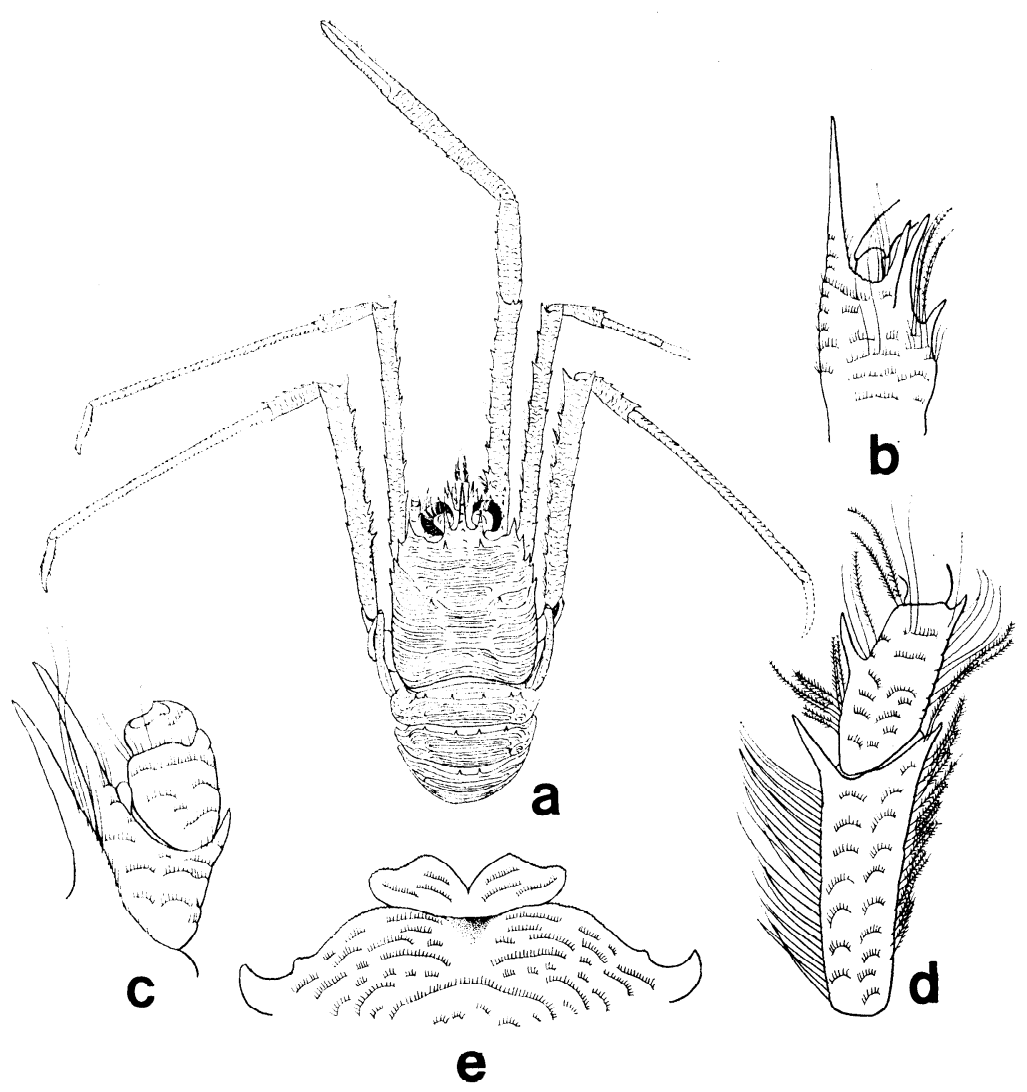

Fig. 4. Munida tenuipes sp. nov.

a, Animal in dorsal view, $\times 0.8$; b, basal segment of left antennule, $\times 5$;

$c$, left antennal peduncle, $\times 5$; $d$, endopod of left third maxilliped, $\times 5$;

e, anterior part of sternal segments, $\times 5$. 
which articulates with palm armed with a spine on each of the dorsal and ventral surface. Fingers not gapped with tubercular teeth on cutting margins; surface without any denticles or spines.

Ambulatory legs devoid of long setae. First ambulatory leg narrower than the third. Merus with about eleven sharp spines on outer (upper) margin, and with seven small spines on inner (lower) margin; each of the inner and outer distal marginal spine being the largest. Carpus with three outer and one inner marginal spines. Propodus slender and more than four times as long as dactylus; inner margin with a slender and movable spine at distal end. Dactylus thickly setose on outer margin; proximal half of inner margin minutely serrated with broad short setae. Second ambulatory leg wanting. Third ambulatory leg broader than the first. Merus with ten strong outer marginal and eight small inner marginal spines, its dorsal surface also armed with eight spinules on proximal portion near the outer margin. Carpus with six outer marginal spines and a small inner distal one. Other portions allied to those of the first $\mathrm{lcg}$.

\section{Measurements in holotype (in $\mathrm{mm}$ ):}

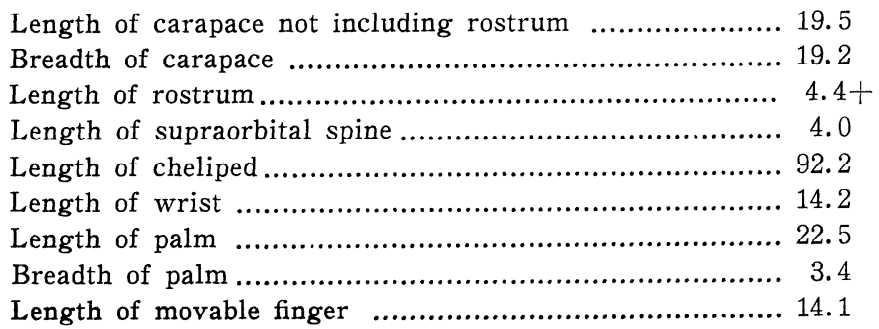

Remarks. The species is easily distinguished from other members of the genus by having a long and slender propodus of the ambulatory leg.

Types. Holotype, male, ZLKU No. 7606; paratype, one male, ZLKU No. 7607 ; off Heta, Suruga Bay, Japan; date unknown; K. Kato leg.

\section{References}

Miyake, S. 1953. On three new species on Galathea from the Western Pacific. J. Fac. Agr., Kyushu Univ., 10 (2) : 199-208, figs. 1-6.

Miyake, S. and K. Baba 1963. A new record for Galathea ternatensis de Man from Kyushu, Japan (Crustacea, Anomura). J. Fac. Agr., Kyushu Univ., 12 (4) : 405-409, figs. $1,2$.

Miyake, S. and K. Baba 1964. Two new species of Galathea from Japan and the East China Sea (Crustacea, Anomura). J. Fac. Agr., Kyushu Univ., 13 (1): 205-211, figs. $1-4$.

Miyake, S. and K. Baba 1965. Some galatheids obtained from the Bonin Islands (Crustacea, Anomura). J. Fac. Agr., Kyushu Univ., 13 (3): 585-593, fig. 1-6. 
Miyake, S. and K. Baba 1966a. Descriptions of galatheids collected from coral reefs of the Ryukyu Islands (Crustacea, Anomura). J. Fac. Agr., Kyushu Univ., 14 (1): 57-79, figs. 1-14.

Miyake, S. and K. Baba 1966b. Two new species of the family Galatheidae from the Tosa Bay, Japan (Crustacea, Anomura). J. Fac. Agr., Kyushu Univ., 14 (1) : 8188, figs. $1-4$

Stimpson, W. 1858. Prodromus descriptionis animalium ..., Pars VII. Crustacea Anomura. Proc. Acad. Nat. Sci., Philadelphia, 10: 225-252. 